\title{
EVALUATION OF PHYSIOLOGICAL TESTS AS PREDICTORS OF YOUNG TREE ESTABLISHMENT AND GROWTH
}

\author{
by Glynn C. Percival
}

\begin{abstract}
High mortality rates of bare-root stock can occasionally occur post-planting due to poor plant vitality at the time of planting. Consequently, physiological tests of plant vitality, such as stem electrolyte leakage, root growth potential (RGP), and chlorophyll fluorescence, are valuable because of their ability to identify low-vigor or damaged plants that will perform poorly when planted into the landscape. The survival, growth, and foliar damage of three tree species commonly used in landscape plantings was accurately predicted by stem electrolyte leakage, RGP, and chlorophyll fluorescence 17 weeks post-planting under field conditions following freezing damage. Of the three physiological tests, correlation of field performance with stem electrolyte leakage had the highest mean $r^{2}$ values, which, based on results of this investigation, was a marginally better predictor of future plant performance compared to chlorophyll fluorescence and RGP. Chlorophyll fluorescence measurements taken from woody tissue of birch (Betula spp.), a deciduous tree species, were highly predictive of subsequent survival, foliar damage, and height increment 17 weeks post-planting, indicating that chlorophyll fluorescence may have applications as a predictor of plant vitality and future growth in deciduous ornamental trees. The practical advantages and disadvantages offered by each plant vitality test to professionals involved in urban tree management are discussed.

Key Words. Chlorophyll fluorescence; electrolyte leakage; root growth potential; freezing damage; holly; evergreen oak; birch; Ilex aquifolium; Quercus ilex; Betula pendula.
\end{abstract}

Occasionally, bare-root ornamental trees and shrubs transplanted in urban landscapes show poor establishment and high mortality rates during the following growing season. At the time of planting, visible differences in plant vitality, such as leaf yellowing and/or crown dieback, are rarely detectable, especially in the case of deciduous stock for which no leaves are present during fall and winter when planting of bare-root stock is recommended. Consequently, depending on the time of planting, it is not until many months later during the spring that such symptoms as leaf yellowing and stem dieback become visibly apparent.

Physiological tests of plant vitality are valuable because of their ability to identify low-vigor or damaged plants that will perform poorly when planted into the landscape (Ritchie and Dunlop 1980; Lindqvist 2001; Lindqvist and Asp 2002).

Shoot electrolyte leakage has been shown to indicate post-planting needle damage and first-year survival of conifer seedlings following heat damage (Binder and Fielder 1995), be highly correlated with incipient damage and growth potential of four conifer species following warm and cold storage (Colombo 1997; Maki and Colombo 2001), and correlate strongly with post-freezing survival rates of fruit trees (Ketchie et al. 1972).

Root growth potential (RGP), a performance test of the ability of nursery stock to initiate and elongate roots in a standardized environment favorable for root growth, has been used extensively to evaluate the effects of environmental and physiological stress on conifer seedlings and is a useful indicator of seedling vitality (McCreary and Duryea 1987; Simpson and Ritchie 1997). However, its use as a predictor of field growth and survival has been an area of debate, emanating primarily from concern about the value of a test performed under ideal conditions predicting performance under field stresses (Mohammed et al. 1997).

Chlorophyll fluorescence, an indication of the fate of excitation energy in the leaf photosynthetic apparatus, has been used to provide a rapid and nondestructive diagnostic system of detecting and quantifying physiological injury in tree leaves and needles (photosynthetic organs) under low temperatures, salinity, and water stress conditions (Palta 1992; Sestak and Stiffel 1997). Chlorophyll fluorescence, especially Fv/Fm (ratio of variable to maximum fluorescence), has proved particularly useful in screening programs because in many instances the effects of environmental stress can be detected prior to visible signs of deterioration (Jimenez et al. 1997; Percival and Fraser 2001; Percival and Sheriffs 2002). Previous work by Mohammed et al. (1997) demonstrated that measurements of chlorophyll fluorescence (Fv/Fm) post heat stress of several stocktypes of jack pine (Pinus banksiana) and black spruce (Picea mariana) were closely correlated with stem volume increment over time, concluding that Fv/Fm measurements could be used to forecast field growth performance of the two test species. Recent work has also shown that chlorophyll fluorescence values were highly predictive of growth, foliar damage, and survival rates in white and red pine (Pinus strobus and $P$. resinosa) and white and black spruce (Picea glauca and $P$. mariana) seedlings at week 7 post-planting following prolonged exposure of seedling material to elevated storage temperatures (Maki and Colombo 2001). 
One of the limitations of using chlorophyll fluorescence as a physiological test of plant vitality at present is the lack of photosynthetic tissue (i.e., leaves) during the dormant season on deciduous trees. Work by Jiang et al. (1999), however, demonstrated that the chlorophyll fluorescence parameter Fv/Fm obtained from freeze-stressed woody vegetative tissue obtained by gently removing the peridermal layer on each side of the terminal branch with a scalpel and measuring the exposed green chlorophyll-containing wood underneath was positively correlated with freeze-stress temperatures and negatively correlated with tissue injury. This finding indicates that fluorescence measurements of the green wood just below the peridermal layer may provide a means of assessing the vitality of deciduous stock and can be used as a possible predictor of future growth.

Although the sensitivity of stem electrolyte leakage, RGP, and chlorophyll fluorescence as predictors of future plant performance has been reported, in most instances conifer seedlings that are rarely planted in urban landscapes have been the test species of choice (Kauppi 1984; Rietveld 1989; Binder and Fielder 1995). In addition, assessments of physiological tests have been correlated with future growth responses of seedlings mainly under glasshouse conditions, which may not reflect plantation establishment success under a field or landscape environment (Binder and Felder 1995; Maki and Columbo 2001).

For the purposes of this investigation, a range of freezing regimes was applied to larger 4-year-old stock $(2+2$ transplants) rather than seedling material of three tree species commonly planted within urban landscapes: birch (Betula pendula), evergreen oak (Quercus ilex), and holly (Ilex aquifolium). Freezing damage to woody plants is known to affect the three physiological tests used in this investigation (chlorophyll fluorescence, RGP, and stem electrolyte leakage) (Ketchie et al. 1972; McKay 1994; Percival and Henderson 2003). Applying a range of freezing regimes to older stock serves two purposes. First, results will permit quantification of the tolerance of the three test species to freezing damage. Second, based on the degree of damage, a range of chlorophyll fluorescence, RGP, and stem electrolyte leakage values can be correlated against future tree responses to evaluate the ability of the three physiological tests to predict changes in young tree growth potential, foliar damage, and survival under field—not glasshouse—conditions.

\section{MATERIALS AND METHODS \\ Plant Material and Experimental Design}

Four-year-old bare-root birch (Betula pendula), evergreen oak (Quercus ilex), and holly (Ilex aquifolium) were obtained from a commercial supplier on 10 December 2001. Immediately upon arrival and to ensure uniformity of stock for experimental purposes, trees were graded, and only those confirming to the physical characteristics specified in Table 1 * were used. Trees were then sorted into bundles of 40 ( $Q$. ilex, I. aquifolium) and 55 (B. pendula). Forty bundled trees for Q. ilex and I. aquifolium [ 25 for physiological tests ( 10 for stem electrolyte leakage and 15 for RGP and chlorophyll fluorescence) and 15 for a field growth trial] and 55 for $B$. pendula (15 extra for chlorophyll fluorescence analysis) were sealed in plastic bags, placed inside larger paper bags, and stored at $6^{\circ} \mathrm{C} \pm 0.5^{\circ} \mathrm{C}\left(43^{\circ} \mathrm{F} \pm 1^{\circ} \mathrm{F}\right)$, a standard storage temperature for trees in the United Kingdom, in a refrigerated cold store in darkness.

\section{Freezing Treatments}

Following 6 weeks at $6^{\circ} \mathrm{C} \pm 0.5^{\circ} \mathrm{C}\left(43^{\circ} \mathrm{F} \pm 1^{\circ} \mathrm{C}\right)$, darkstorage trees were removed from cold store (21 January 2002) and placed in a Merck environmental freezing chamber and the temperature reduced by $2^{\circ} \mathrm{Ch}^{-1}\left(3.8^{\circ} \mathrm{F} \mathrm{h}^{-1}\right)$ from $10^{\circ} \mathrm{C}$ to $0^{\circ} \mathrm{C},-2^{\circ} \mathrm{C},-4^{\circ} \mathrm{C},-6^{\circ} \mathrm{C},-8^{\circ} \mathrm{C}$, and $-10^{\circ} \mathrm{C}$ $\left(50^{\circ} \mathrm{F}\right.$ to $32^{\circ} \mathrm{F}, 28^{\circ} \mathrm{F}, 25^{\circ} \mathrm{F}, 21^{\circ} \mathrm{F}, 18^{\circ} \mathrm{F}$, and $\left.14^{\circ} \mathrm{F}\right)$. Each respective temperature was maintained for 4 hours, after which the temperature was raised by $2^{\circ} \mathrm{Ch}^{-1}$ to $10^{\circ} \mathrm{C}$. There was one bag of 40 (Q. ilex, I. aquifolium) and 55 (B. pendula) young trees per species for each respective temperature treatment. Trees stored at $6^{\circ} \mathrm{C}$ served as controls.

\section{Physiological Tests}

Stem Electrolyte Leakage. Quantitative damage to stem cell tissue was assessed by measuring electrolyte leakage on the terminal $2 \mathrm{~cm}$ (0.8 in.) of the shoot from 10 randomly chosen seedlings per freezing treatment. Shoot tips were excised and placed in $30 \mathrm{~mL}(0.9 \mathrm{oz})$ universal bottles containing $20 \mathrm{~mL}$ (0.6 oz) distilled water. Samples were stored at $22^{\circ} \mathrm{C}\left(72^{\circ} \mathrm{F}\right)$ for 24 hours in darkness prior to conductivity measurements using a Jenway conductivity probe and M4070 meter (BDH, Leicestershire, Loughborough, UK). Total solute leakage was obtained by autoclaving for 1 hour at $121^{\circ} \mathrm{C}\left(250^{\circ} \mathrm{F}\right)$ and $0.103 \mathrm{MPa}$. Results are presented as percentage of solute leakage after 24 hours.

Root Growth Potential (RGP). Fifteen randomly chosen young trees per treatment were potted into $5 \mathrm{~L}$ (1.3 gal) pots (loamy texture, with $23 \%$ clay, $46 \%$ silt, $31 \%$ sand, $3.1 \%$ organic carbon, $\mathrm{pH} 6.6)$ and placed under glasshouse conditions at a temperature of $22^{\circ} \mathrm{C}\left(72^{\circ} \mathrm{F}\right) \pm 2^{\circ} \mathrm{C}\left(3.8^{\circ} \mathrm{F}\right)$ supplemented with $400 \mathrm{~W}$, high-pressure sodium lamps (SON/T) providing a photoperiod of 16 hours of light and 8 hours of dark and minimum $250 \mu \mathrm{mol} \mathrm{m}^{-2} \mathrm{~s}^{-1}$ photosynthetically active radiation (PAR) at the tree crown and relative humidity (minimum of 75\%). Trees were watered as required, generally twice per week, and RGP was assessed by counting the number of white root tips $\geq 1 \mathrm{~cm}(0.4 \mathrm{in}$.), on the 15 potted young trees per treatment after 28 days under glasshouse conditions. No fertilizer was applied to any of the test species during the 28-day period. 
Chlorophyll Fluorescence. Two days after potting and placing under glasshouse conditions following freezing, the three upper apical leaves (Q. ilex, I. aquifolium) of the terminal stem were adapted to darkness for 30 minutes by attaching light exclusion clips to the leaf surface, and chlorophyll fluorescence was measured using a HandyPEA portable fluorescence spectrometer (Hansatech Instruments, Ltd., King's Lynn, UK). Measurements were recorded up to 1 second with a data acquisition rate of $10 \mu$ s for the first $2 \mathrm{~ms}$ and of $1 \mathrm{~ms}$ thereafter. The fluorescence responses were induced by a red (peak at $660 \mathrm{~nm}$ ) light of $1,500 \mu \mathrm{mol} \mathrm{m}^{-2} \mathrm{~s}^{-1}$ photosynthetically active radiation (PAR) intensity provided by an array of six light-emitting diodes.

The ratio of variable $(\mathrm{Fv}=\mathrm{Fm}-\mathrm{Fo})$ to maximal $(\mathrm{Fm})$ fluorescence (i.e., Fv/Fm, where Fo = minimal fluorescence) of dark-adapted leaves was used to quantify the detrimental effects of freezing on leaf tissue. Fv/Fm is considered a quantitative measure of the maximal or potential photochemical efficiency or optimal quantum yield of photosystem II (Willits and Peet 2001). Likewise, Fv/Fm value is the most popular index used as a measure of plant vitality and early diagnosis of stress (Maxwell and Johnson 2000). Because leaf chlorophyll fluorescence measurements are noninvasive and nondestructive, in the case of Q. ilex and I. aquifolium, the same trees were used for RGP measurements. In the case of B. pendula, where no leaf material was present, chlorophyll fluorescence measurements were made by gently removing the peripheral peridermal layer on each side of the terminal branch with a scalpel and inserting the exposed wood into the sample light exclusion clip (Jiang et al. 1999). Two readings per tree were made. Due to the possibility that the minor damage made to the terminal stem may have influenced RGP values, these trees were then discarded, and the remaining 15 extra undamaged trees were used to obtain RGP values.

\section{Statistical Analysis}

Stem electrolyte leakage (10 replications), chlorophyll fluorescence (45 replications, Q. ilex and I. aquifolium; 30 replications, B. pendula), and RGP (15 replications), as well as significant interactions between freezing and species on each parameter, were determined by both two- and one-way analyses of variance (ANOVA) following checks for normality and equal variance distributions. Dunn's or Dunnett's tests (for unequal and equal sample sizes, respectively) were then used to compare the six freezing treatments to the control values using the Genstat V program.

Growth Potential and Damage Assessment. Fifteen randomly chosen trees per freezing treatment of each species were planted by hand in three randomized blocks (five trees per block) in field research plots at the University of Reading, Shinfield Experimental Station, Reading, UK, at 2 m (6.6 ft) spacing on January 22, 2002. Each block was planned in a square formation to minimize possible effects of any gradients in soil conditions. The soil was a sandy loam containing $4 \%$ to $6 \%$ organic matter with a pH of 6.2 . Weeds were controlled chemically using glyphosate (Roundup) prior to planting, and by hand during the trial. During the 17 -week growing period, the mean minimum and maximum air temperatures were $4.5^{\circ} \mathrm{C}\left(40^{\circ} \mathrm{F}\right)$ and $13.4^{\circ} \mathrm{C}\left(56^{\circ} \mathrm{F}\right)$, respectively; daily relative humidity, sunshine hours, and rainfall were $79.7 \%, 4.45$ hours, and $1.8 \mathrm{~cm}(0.7 \mathrm{in}$.), respectively; the soil surface temperature was $0.4^{\circ} \mathrm{C}\left(33^{\circ} \mathrm{F}\right)$; and soil temperatures at $20 \mathrm{~cm}$ (8 in.) depth averaged $8.5^{\circ} \mathrm{C}$ $\left(47^{\circ} \mathrm{F}\right)$ (Reading University Meteorological Dept.,

Whiteknights, Reading, UK). No watering was required and no fertilizer was applied to any of the test species during the 17-week post-planting period. After 17 weeks (21 May 2002), height increment of new terminal shoots was measured, and survival and foliar damage (percentage of defoliation and/or browning of leaves on surviving trees) were visually estimated. Survival and foliar damage percentages were transformed [arcsine $\left(x^{0.5}\right)$ ]. Height increment and the transformed survival and foliar damage data for each species were subjected to two-way [ 7 treatments ( 1 control +6 freezing treatments) -3 blocks] ANOVA followed by Dunn's or Dunnett's nonparametric or Bonferroni's parametric all-treatments versus control multiple comparison procedures.

Determination of Freezing Tolerance. The three tree performance attributes (height increment, survival, and foliar damage) were used to define freezing tolerance. A species was deemed tolerant of each temperature up to the duration at which any one of the three attributes was significantly impaired relative to the control but only if all longer durations at a tested temperature were also significantly impaired for that affected attribute.

Assessment of Physiological Test Effectiveness. The ability to predict foliar damage, survival, and height growth was assessed by correlation analysis of the three physiological tests with the three field trial attributes of damage and growth. Correlation equations and coefficients of determination $\left(\mathrm{r}^{2}\right)$ were calculated using the curve-fitting feature of SlideWrite using quadratic polynomial, two-parameter exponential growth or decay, or simple linear models as appropriate to which model gave the highest percentage variation accounted for (i.e., $\mathrm{r}^{2}$ value).

\section{RESULTS}

\section{Tolerance of Young Trees to Freezing}

Post-freezing Fv/Fm was reduced to between $62.5 \%$ and 91.9\% of the control values depending on species (Table 2). Significant differences $(\mathrm{P}<0.05)$ in the reduction of $\mathrm{Fv} / \mathrm{Fm}$ were recorded between species, with birch appearing to be the most resistant to freezing of the three species tested and 
holly the most freezing sensitive. Freezing also had a significant effect $(\mathrm{P}<0.05)$ on stem electrolyte leakage, with values reduced from $88 \%$ to $95.7 \%$ of controls (Table 2). Reductions in stem electrolyte leakage reflected species tolerance based on $\mathrm{Fv} / \mathrm{Fm}$ values, with birch again appearing to be the most freezing resistant and holly the most sensitive. Irrespective of species, RGP was markedly reduced 28 days post-freezing under glasshouse conditions. The greatest reduction in RGP, compared to the control values, was recorded in evergreen oak (84.3\%), followed by birch (78.9\%) and holly (77.4\%). Irrespective of species, little variation existed between stem electrolyte leakage values of controls (ranging from $2.16 \%$ to $2.79 \%$ ). Likewise, pre-treatment Fv/Fm values of evergreen oak and holly were 0.795 and 0.790 , respectively. However, pre-treatment values for birch were markedly lower (0.681), possibly as a result of differences in $\mathrm{Fv} / \mathrm{Fm}$ values between leaf and periderm tissue used for chlorophyll fluorescence measurements. Large variability in pre-treatment RGP values between species was recorded. Values ranged from 10.13 (birch) to 7.07 (holly) to 4.27 (evergreen oak). Irrespective of species, significant detrimental effects $(\mathrm{P}<0.05)$ on Fv/ Fm, RGP, and stem electrolyte were recorded following freezing at $\geq-2^{\circ} \mathrm{C}\left(28^{\circ} \mathrm{F}\right)$. A significant influence $(\mathrm{P}<0.001)$ of species, freezing, and species $\times$ freezing interaction on the variates Fv/Fm, RGP, and stem electrolyte was recorded in this investigation (Table 2).

Seventeen weeks post-freezing under field conditions, height increment was reduced by $55.1 \%, 85.2 \%$, and $85.1 \%$ of the control values in birch, holly, and evergreen oak, respectively (Table 2). Likewise, foliar damage 17 weeks post-freezing was increased to between $92.3 \%$ and $95.2 \%$ of the control values, depending on species (Table 2). Significant effects on height increment and foliar damage were manifest post-freezing at $\geq-2^{\circ} \mathrm{C}\left(28^{\circ} \mathrm{F}\right)$ (Table 2). Effects on survival were recorded post-freezing at $-4^{\circ} \mathrm{C}\left(25^{\circ} \mathrm{F}\right)$ for birch and evergreen oak, and at $-6^{\circ} \mathrm{C}\left(21^{\circ} \mathrm{F}\right)$ for holly. Freezing tolerance based on survival 17 weeks post-freezing at $-10^{\circ} \mathrm{C}\left(14^{\circ} \mathrm{F}\right)$, however, was in the order of birch (47.7), evergreen oak (27.0), and holly (6.7). Irrespective of species, little variation existed between foliar damage values of controls (ranging from $2.4 \%$ to $6.7 \%$ ). Likewise, survival rates in control trees of all three species tested were $100 \%$. Large variability in height increment between controls of each species was recorded. Values ranged from 182.13 (birch) to 83.84 (evergreen oak) to 73.23 (holly).

\section{Predictive Ability of Physiological Tests}

All physiological tests of young trees measured after freezing were highly correlated to height increment, foliar damage, and survival under field conditions for 17 weeks (Table 3 and Figures 1-3). Stem electrolyte leakage proved to be the best predictor of foliar damage for all three species $\left(r^{2}=0.96\right)$, whereas relationships between chlorophyll fluorescence and survival were strongest for all three species, with a mean $\mathrm{r}^{2}$ of 0.94 (Table 3). RGP proved to be the best predictor of height increment for all three species $\left(r^{2}=0.85\right)$. Of the three physiological tests considered, (chlorophyll fluorescence, RGP, and stem electrolyte leakage), correlations of field performance with stem electrolyte leakage had the highest mean $\mathrm{r}^{2}$ values ( 0.93 to 0.63; Table 3).

Chlorophyll fluorescence was highly correlated to foliar damage, height, and survival in all species (Figure 1, Table 3). Values for $\mathrm{r}^{2}$ ranged from 0.94 (holly) to 0.98 (birch and evergreen oak) for survival; 0.98 (birch) to 0.99 (holly and evergreen oak) for foliar damage, and 0.96 (holly) to 0.99 (birch and evergreen oak) for height increment (Figure 1). Highly significant relationships between chlorophyll fluorescence and all three performance attributes were obtained using quadratic polynomial and linear regression models (Figure 1). For the quadratic polynomial curves of RGP versus survival, $\mathrm{r}^{2}$ ranged from 0.93 for evergreen oak to 0.98 for birch and holly (Figure 2). Likewise, for the quadratic polynomial curves of RGP versus foliar damage, $\mathrm{r}^{2}$ ranged from 0.96 for evergreen oak to 0.99 for holly. Linear and quadratic polynomial curves were used to describe the relationship of height increment to RGP; in these cases, $\mathrm{r}^{2}$ ranged from 0.94 (evergreen oak) to 0.99 (holly; Figure 2). Stem electrolyte leakage was highly correlated to foliar damage, height, and survival in all species using quadratic polynomial and linear regression models (Figure 3, Table 3). Values for $\mathrm{r}^{2}$ ranged from 0.95 (birch) to 0.99 (evergreen oak) for survival; 0.95 (birch) to 0.99 (holly and evergreen oak) for foliar damage, and 0.94 (birch) to 0.99 (holly) for height increment (Figure 3).

\section{DISCUSSION \\ Tolerance of Young Trees to Freezing}

Current nursery practices in Europe and North America rely on the rapid production of immature woody plants grown in small containers. Such intensive husbandry renders the plants very susceptible to stress-induced injury. Freezing temperatures, especially late spring frosts, can be devastating to leaf tissue of woody plants and are a major source of injury resulting in reduced plant quality and often death (Cannell and Smith 1983; Cameron and Dixon 1997). Indeed, it has been estimated that freezing damage is indirectly and directly responsible for the deaths of more than 1 million urban trees annually on a global basis (Sakai and Larcher 1987). Selection criteria against freezing damage will become more important because climatic change may increase the unpredictability of weather patterns, resulting in progressively later frosts on an annual basis (Biggs 1996). Survival rates among the three test 
species were not affected until a freezing stress of $\geq-4^{\circ} \mathrm{C}$ $\left(25^{\circ} \mathrm{F}\right)$ (birch and evergreen oak) and $-6^{\circ} \mathrm{C}\left(21^{\circ} \mathrm{F}\right)$ (holly) was imposed (Table 2). Freezing tolerance based on survival 17 weeks post-freezing at $-10^{\circ} \mathrm{C}\left(14^{\circ} \mathrm{F}\right)$, however, was in the order birch > evergreen oak > holly. This finding indicates that holly is better able to withstand moderate freezing stress compared with birch and evergreen oak, yet following severe freezing, damage birch and evergreen oak are more ideally suited.

\section{Predictive Ability of Physiological Tests}

All physiological tests of young trees used in this investigation were highly correlated to height increment, foliar damage, and survival under field conditions at week 17 post-freezing (Table 3 and Figures 1-3). Of the three physiological tests considered, correlations of field performance with stem electrolyte leakage had the highest mean $\mathrm{r}^{2}$ values (Table 3) and, therefore, based on results of this investigation, were marginally better as a predictor of future plant performance compared to chlorophyll fluorescence and RGP. This trial found a strong relationship between growth and RGP, stem electrolyte leakage, and chlorophyll fluorescence, and is one of few investigations to use these measures as predictors of plantation establishment success in a field scenario that is more representative of landscape conditions. Likewise, young $2+2$ transplants are generally used in preference to seedling material when establishing amenity plantings; therefore, they were used in this trial instead of seedling material as commonly used in other investigations (McCreary and Duryea 1987; McKay 1992, 1994; Simpson and Ritchie 1997).

Stem electrolyte leakage indicates tissue damage resulting in the loss of cell membrane semi-permeability (Cameron and Dixon 1997). Advantages of stem electrolyte leakage as a system to measure plant vitality include the simple nature of the task along with a requirement of only 48 hours to complete (Ketchie et al. 1972). Practical disadvantages of stem electrolyte leakage measurements include a requirement for laboratory facilities and the destructive nature of the assay (Figueiredo 1985). Although measurements of stem electrolyte leakage were used as predictors of future growth responses in this investigation, fine root electrolyte leakage is the more commonly used test to determine plant vitality (McKay and Mason 1991; McKay 1992, 1994). Root electrolyte leakage was not considered in this investigation due to the practical difficulty of collecting root samples from trees in urban sites where roots frequently grow beneath roads and pavements. The fact that stem tissue can be obtained at any time means estimates of vitality can be determined through out the year if required.

RGP is probably the most widely used method to assess seedling viability and vigor (McCreary and Duryea 1987; Dunsworth 1997). The test is inexpensive to conduct if a controlled growth environment is available. However, RGP testing is destructive and, as in this study, requires 28 days to obtain results, although a 14-day test has provided meaningful results elsewhere (Maki and Columbo 2001). In addition, RGP varies by species, so that a database of acceptable levels of performance is usually a prerequisite to using this test operationally to assess young tree condition. Indeed, in the current study, the highest mean RGP for birch was 10.1 (new roots), while for evergreen oak it was 4.7. Despite these differences in magnitude among the species tested, RGP had the highest predictive ability for height increment of the three physiological tests evaluated (Table 3 and Figures 1-3). Consequently, this gives cause to consider the operational use of RGP to grade stock according to performance potential prior to leaving a nursery and planting in situ. Numerous reports exist of positive relationships between RGP and seedling growth and survival after planting (Simpson and Ritchie 1997), and the present study offers further evidence in this regard. Nevertheless, the view has been stated that tests such as RGP should not be used to predict field performance because correlations with field performance are at times poor or absent (Binder et al. 1988; Simpson and Ritchie 1997).

Chlorophyll fluorescence is a method for studying how environmental factors influence photosynthetic efficiency (Lichtenthaler and Rinderle 1988). The chlorophyll fluorescence measurement Fv/Fm has been shown to be a useful estimator of photosystem II quantum efficiency and an indirect measurement of plant physiological status (Maxwell and Johnson 2000). In this investigation, relationships between chlorophyll fluorescence and survival were strongest for all three test species (Figure 1, Table 3), a result supported elsewhere (Maki and Columbo 2001). $\mathrm{Fv} / \mathrm{Fm}$ measurements of healthy, nonstressed plants are associated with values ranging from 0.78 to 0.85 (Demmig and Björkman 1987). However, results here and by Maki and Columbo (2001) indicated a threshold fluorescence value of about 0.6 above which trees were unaffected in survival, height growth, and foliar damage (Table 2, Figures 1-3). Although the physiological principles of chlorophyll fluorescence are complex, the operation of the fluorimeter used in this trial is simple. The practical advantages of using chlorophyll fluorescence include the fact that fluorescence measurements use a light, portable piece of equipment; measurements are nondestructive and noninvasive; and readings are obtained in less than 1 second, allowing for many trees to be evaluated in a single day. The fluorescence value $\mathrm{Fv} / \mathrm{Fm}$ has been shown to be a sensitive and rapid method of assessing woody tissue viability in birch following freezing stress and can be used as a reliable predictor of foliar damage, growth, and survival under field conditions. However, this work was conducted on one species of one genus and, although preliminary results are promising, further work 
is needed to assess the applicability and limits of this method for other ornamental tree species. One of the major limitations of fluorescence analysis at present is the initial cost of the fluorimeter, which can retail at more than US\$5,000.

The strong relationship between two of the physiological tests (stem electrolyte leakage and chlorophyll fluorescence) and survival of all three test species in this investigation and conifer species elsewhere (Maki and Columbo 2001) may have other implications for professionals involved in urban tree management. Stress detection in woody plants relies heavily on visual observations of, for example, leaf yellowing, crown dieback, and other factors. Such indicators can be subjective because they are based on human knowledge and interpretation, which can differ among individuals. Consequently, tree health evaluations can differ markedly among assessors. Use of stem electrolyte leakage and/or chlorophyll fluorescence may aid in the decision-making process by quantifying the odds of survival following a prolonged period of stress such as drought or waterlogging, in turn determining the economic feasibility of applying remedial measures or tree removal. Further research in this area is warranted using a wider range of species at different stages of maturity so that "thresholds of concern" can be identified before symptoms of physical deterioration are observed, which, if ignored may, with time, make the tree a potential danger to people and property.

In conclusion, RGP, chlorophyll fluorescence, and shoot tip electrolyte leakage were all able to predict when freezing temperatures caused damage and reduced tree vigor. A high correlation between chlorophyll fluorescence obtained from woody tissue and foliar damage, height, and survival indicates a useful potential of this system to evaluate the vitality and predict the future performance of deciduous ornamental stock that has been subjected to freezing stress. The ability of all three physiological tests to predict damage and subsequent growth supports the continued use of these measures as operational tools to measure plant viability.

\section{LITERATURE CITED}

Biggs, M. 1996. Low-temperature acclimation and associated physiological changes in species of Rhododendron. Ph.D. thesis. University of Strathclyde/SAC Auchincruive, Scotland, UK.

Binder, W.D., and P. Fielder. 1995. Heat damage in boxed white spruce (Picea glauca [Moench.] Voss) seedlings: Its pre-planting detection and effect on field performance. New For. 9:237-259.

Binder, W.D., R.K. Skagel, and G.J. Krumlik. 1988. Root growth potential: Facts, myths, value?, pp 111-118. In Landis, T.D. (Tech. Coord.). Proceedings of the 1988 Combined Meeting of the Western Forest Nursery Association, Vernon, BC, 8-11 August 1988. USDA Forest Service Gen. Tech. Rep. RM-167.
Cameron, R.W.F, and G.R. Dixon. 1997. Air temperature, humidity and rooting volume affecting freezing injury to Rhododendron and other perennials. J. Hortic. Sci. Biotech. 72(4):553-562.

Cannell, M.G.R., and R.I. Smith. 1983. Thermal time, chill days and prediction of budburst in Picea sitchensis. J. Appl. Ecol. 20:951-963.

Colombo, S.J. 1997. Frost hardening spruce container stock for overwintering in Ontario. New For. 13:449-467.

Demmig, B., and O. Björkman. 1987. Comparison of the effect of excessive light on chlorophyll fluorescence $(77 \mathrm{~K})$ and photon yield of $\mathrm{O}^{2}$ evolution in leaves of higher plants. Planta 171:171-184.

Dunsworth, G.B. 1997. Plant quality assessment: An industrial perspective. New For. 13:439-448.

Figueiredo, P. 1985. Frost and freezing injury to crop plants-A literature review. Swedish University of Agricultural Sciences, Uppsala, Report 155.

Jiang, H., G.S. Howell, and J.A. Flore. 1999. Efficacy of chlorophyll fluorescence as a viability test for freezestressed woody grape tissue. Can. J. Plant Sci. 79:401409.

Jimenez,M.S., A.M. Gonzalez-Rodriguez, D. Morales, M.C. Cid, A.R. Socorro, and M. Caballero. 1997. Evaluation of chlorophyll fluorescence as a tool for salt stress detection in roses. Photosynthetica 33(2):291-301.

Kauppi, P. 1984. Stress, strain and injury: Scots pine transplants from lifting to acclimation on the planting site. Acta For. Fenn. 185:1-49.

Ketchie, D.O., C.H. Beeman, and A.L. Ballard. 1972. Relationship of electrolytic conductance to cold injury and acclimation in fruit trees. J. Am. Soc. Hortic. Sci. 97(3):403-406.

Lichtenthaler, H.K., and U. Rinderle. 1988. The role of chlorophyll fluorescence in the detection of stress conditions in plants. Crit. Rev. Analyt. Chem. 19:S29S85.

Lindqvist, H. 2001. Effects of different lifting date and different lengths of cold storage on plant vitality of silver birch and common oak. Sci. Hortic. 88:147-161.

Lindqvist, H., and H. Asp. 2002. Effects of lifting date and storage time on changes in carbohydrate content and photosynthetic efficiency in three deciduous species. J. Hortic. Sci. Biotech. 77(3): 346-354.

Maki, D.S., and S.J. Colombo. 2001. Early detection of the effects of warm storage on conifer seedlings using physiological tests. For. Ecol. Manage. 154:237-249.

Maxwell, K., and G.N. Johnson. 2000. Chlorophyll fluorescence-A practical guide. J. Exper. Bot. 51:659-668.

McCreary, D.D., and M.L. Duryea. 1987. Predicting performance of Douglas-fir seedlings: Comparisons of root growth potential vigor and plant moisture stress. New For. 3:153-169. 
McKay, H.M. 1992. Electrolyte leakage from fine roots of conifer seedlings: A rapid index of plant vitality following cold storage. Can. J. For. Res. 22:1371-1377.

- 1994. Frost hardiness and cold storage tolerance of the root system of Picea sitchensis, Pseudotsuga menziesii, Larix kaempferi and Pinus sylvestris bare root seedlings. Scand. J. For. Res. 9:203-213.

McKay, H., and W.L. Mason. 1991. Physiological indicators of tolerance to cold storage in Sitka spruce and Douglasfir seedlings. Can. J. For. Res. 21:890-901.

Mohammed. G.H., T.L. Noland, W.C. Parker, and R.G. Wagner. 1997. Pre-planting physiological stress assessment to forecast field growth performance of jack pine and black spruce. For. Ecol. Manage 92:107-117.

Palta, J.P. 1992. Mechanisms for obtaining freezing stress resistance in herbaceous plants, pp 219-250. In Stalker, H.P., and J.T. Murphy (Eds.) Plant Breeding in the 1990s: Proceedings of the Symposium on Plant Breeding in the 1990s, North Carolina State University, Raleigh, NC March 1991. CAB International Press, Wallingford, UK.

Percival, G.C., and G.A. Fraser. 2001. Measurement of the salinity and freezing tolerance of Crataegus genotypes using chlorophyll fluorescence. J. Arboric. 27(5):233245.

Percival, G.C., and A. Henderson. 2003. An assessment of the freezing tolerance of urban trees using chlorophyll fluorescence. J. Hortic. Sci. Biotech. 78:254-260.

Percival, G.C., and C. Sheriffs. 2002. Identification of drought-tolerant woody perennials using chlorophyll fluorescence. J. Arboric. 28(5):215-224.
Rietveld, W.J. 1989. Transplanting stress in bareroot conifer seedlings: Its development and progression to establishment. North. J. Appl. For. 6:99-107.

Ritchie, G.A., and J.R. Dunlop. 1980. Root growth potential: Its development and expression in forest tree seedlings. N.Z. J. For. Sci. 10:218-248.

Sakai, A., and W. Larcher. 1987. Frost Survival of PlantsResponses and Adaptations to Freezing Stress. SpringerVerlag, London, UK.

Sestak, Z., and P. Stiffel. 1997. Leaf age-related differences in chlorophyll fluorescence. Photosynthetica 33 (3-4):347-369.

Simpson, D.G., and G.A. Ritchie. 1997. Does RGP predict field performance? A debate. New For. 13:253-277.

Willits, D.H., and M.M. Peet. 2001. Using chlorophyll fluorescence to model leaf photosynthesis in greenhouse pepper and tomato. Acta Hortic. 507:311-315

Acknowledgments. The author is grateful for funding from the TREE Fund (Hyland Johns Grant).

\author{
R.A. Bartlett Tree Research Laboratory, Europe \\ The University of Reading \\ 2 Early Gate \\ Whiteknights \\ Reading, RG6 6AU \\ United Kingdom
}

Table 1. Physical characteristics of birch (Betula pendula), holly (Ilex aquifolium), and evergreen oak (Quercus ilex) after grading.

\begin{tabular}{llll}
\hline Attribute & Birch & Holly & Evergreen oak \\
\hline Height $(\mathrm{cm})$ & $98.3(3.85)$ & $37.5(0.13)$ & $46.0(1.38)$ \\
Girth $(\mathrm{cm})$ & $3.1(0.13)$ & $1.8(0.06)$ & $2.5(0.09)$ \\
Height:girth ratio $(\mathrm{cm} / \mathrm{cm})$ & $31.7(1.21)$ & $20.8(0.83)$ & $18.4(0.64)$ \\
Shoot dry weight $(\mathrm{g})$ & $22.9(0.97)$ & $3.8(0.14)$ & $10.2(0.41)$ \\
Root dry weight $(\mathrm{g})$ & $32.7(1.39)$ & $1.3(0.04)$ & $24.2(0.68)$ \\
Shoot:root ratio $(\mathrm{g} / \mathrm{g})$ & $0.70(0.037)$ & $2.5(0.10)$ & $0.42(0.01)$ \\
Root area $\left(\mathrm{cm}^{2}\right)$ & $707.0(43.28)$ & $26.0(0.88)$ & $93.4(2.71)$ \\
\hline
\end{tabular}

Values are mean and standard errors for 20 trees. 
Table 2. Physiological responses and growth attributes of freezing on birch (Betula pendula), holly (Ilex aquifolium), and evergreen oak (Quercus ilex) trees.

\begin{tabular}{|c|c|c|c|c|c|c|}
\hline Treatment & $\begin{array}{l}\text { Stem electrolyte } \\
\text { leakage }(\%) \\
(n=10)\end{array}$ & $\begin{array}{l}\text { Chlorophyll } \\
\text { fluorescence }(\mathrm{Fv} / \mathrm{Fm}) \\
\text { (I. aquifolium, } \\
\text { Q. ilex, } n=45) \\
\text { (B. pendula, } n=30 \text { ) }\end{array}$ & $\begin{array}{l}\text { RGP (number } \\
\text { of roots } \geq 1 \mathrm{~cm}) \\
(n=15)\end{array}$ & $\begin{array}{l}\text { Height } \\
\text { increment (mm) } \\
(n=15)\end{array}$ & $\begin{array}{l}\text { Survival \% } \\
(n=15)\end{array}$ & $\begin{array}{l}\text { Foliar damage } \\
(n=15)\end{array}$ \\
\hline \multicolumn{7}{|l|}{ Birch } \\
\hline Control $\left(6^{\circ} \mathrm{C}\right)$ & $2.16 \mathrm{a}^{*}$ & $0.681 \mathrm{e}$ & $10.13 \mathrm{~d}$ & $182.13 \mathrm{e}$ & $100 \mathrm{a}$ & $2.4 \mathrm{a}$ \\
\hline $0^{\circ} \mathrm{C}$ & $2.26 \mathrm{a}$ & $0.678 \mathrm{e}$ & $10.67 \mathrm{~d}$ & $189.93 \mathrm{e}$ & $100 \mathrm{a}$ & $2.8 \mathrm{a}$ \\
\hline$-2^{\circ} \mathrm{C}$ & $3.80 \mathrm{~b}$ & $0.614 \mathrm{~d}$ & $8.67 c$ & $167.53 \mathrm{~d}$ & $100 \mathrm{a}$ & $5.5 \mathrm{~b}$ \\
\hline$-4^{\circ} \mathrm{C}$ & $4.47 \mathrm{~b}$ & $0.605 \mathrm{~d}$ & $9.25 \mathrm{~cd}$ & $147.21 \mathrm{c}$ & $93 \mathrm{a}$ & $5.9 \mathrm{~b}$ \\
\hline$-6^{\circ} \mathrm{C}$ & $6.28 c$ & $0.549 c$ & $6.60 \mathrm{~b}$ & $128.58 \mathrm{~b}$ & $80 \mathrm{~b}$ & $17.3 c$ \\
\hline$-8^{\circ} \mathrm{C}$ & $13.95 \mathrm{~d}$ & $0.520 \mathrm{~b}$ & $5.68 \mathrm{~b}$ & $120.73 b$ & $73 \mathrm{~b}$ & $22.5 \mathrm{~d}$ \\
\hline$-10^{\circ} \mathrm{C}$ & $18.07 \mathrm{e}$ & $0.255 \mathrm{a}$ & $2.13 \mathrm{a}$ & $81.71 \mathrm{a}$ & $47 \mathrm{c}$ & $47.4 \mathrm{e}$ \\
\hline \multicolumn{7}{|l|}{ Holly } \\
\hline Control $\left(6^{\circ} \mathrm{C}\right)$ & $2.34 \mathrm{a}$ & $0.790 \mathrm{f}$ & $7.07 \mathrm{de}$ & $73.23 \mathrm{ef}$ & $100 \mathrm{a}$ & $4.1 \mathrm{a}$ \\
\hline $0^{\circ} \mathrm{C}$ & $2.30 \mathrm{a}$ & $0.788 \mathrm{f}$ & $7.46 \mathrm{e}$ & $77.7 \mathrm{f}$ & $100 \mathrm{a}$ & $4.6 \mathrm{a}$ \\
\hline$-2^{\circ} \mathrm{C}$ & $3.23 \mathrm{a}$ & $0.726 \mathrm{e}$ & $6.86 \mathrm{de}$ & $68.51 \mathrm{de}$ & $100 \mathrm{a}$ & $6.3 \mathrm{a}$ \\
\hline$-4^{\circ} \mathrm{C}$ & $4.82 \mathrm{a}$ & $0.664 \mathrm{~d}$ & $6.20 \mathrm{~d}$ & $65.45 \mathrm{~d}$ & $100 \mathrm{a}$ & $10.7 \mathrm{~b}$ \\
\hline$-6^{\circ} \mathrm{C}$ & $5.21 \mathrm{a}$ & $0.642 c$ & $4.87 c$ & $56.61 \mathrm{c}$ & $80 \mathrm{~b}$ & $21.3 c$ \\
\hline$-8^{\circ} \mathrm{C}$ & $37.57 \mathrm{~b}$ & $0.218 \mathrm{~b}$ & $3.13 \mathrm{~b}$ & $43.07 \mathrm{~b}$ & $67 \mathrm{~b}$ & $55.5 \mathrm{~d}$ \\
\hline$-10^{\circ} \mathrm{C}$ & $54.08 \mathrm{c}$ & $0.070 \mathrm{a}$ & $1.60 \mathrm{a}$ & $10.84 \mathrm{a}$ & $6.7 c$ & $86.4 \mathrm{e}$ \\
\hline \multicolumn{7}{|l|}{ Evergreen oak } \\
\hline Control $\left(6^{\circ} \mathrm{C}\right)$ & $2.79 a$ & $0.795 \mathrm{f}$ & $4.27 \mathrm{e}$ & 83.84 ef & $100 \mathrm{a}$ & $6.6 \mathrm{a}$ \\
\hline $0^{\circ} \mathrm{C}$ & $2.97 \mathrm{a}$ & $0.795 \mathrm{f}$ & $4.13 \mathrm{e}$ & $87.67 \mathrm{f}$ & $100 \mathrm{a}$ & $6.1 \mathrm{a}$ \\
\hline$-2^{\circ} \mathrm{C}$ & $3.82 \mathrm{a}$ & $0.679 \mathrm{e}$ & $3.06 \mathrm{~d}$ & $79.87 \mathrm{e}$ & $100 \mathrm{a}$ & $7.9 \mathrm{a}$ \\
\hline$-4^{\circ} \mathrm{C}$ & $4.49 \mathrm{a}$ & $0.657 \mathrm{~d}$ & $2.80 \mathrm{~cd}$ & $66.14 \mathrm{~d}$ & $93 \mathrm{a}$ & $7.5 \mathrm{a}$ \\
\hline$-6^{\circ} \mathrm{C}$ & $16.33 \mathrm{~b}$ & $0.468 c$ & $1.80 \mathrm{~b}$ & $54.28 c$ & $67 \mathrm{~b}$ & $23.0 \mathrm{~b}$ \\
\hline$-8^{\circ} \mathrm{C}$ & $30.56 c$ & $0.269 \mathrm{~b}$ & $1.87 \mathrm{bc}$ & $33.17 \mathrm{~b}$ & $40 c$ & $51.3 \mathrm{c}$ \\
\hline$-10^{\circ} \mathrm{C}$ & $36.47 \mathrm{~d}$ & $0.116 \mathrm{a}$ & $0.67 \mathrm{a}$ & $12.43 \mathrm{a}$ & $27 \mathrm{~d}$ & $86.7 \mathrm{~d}$ \\
\hline
\end{tabular}

"Means followed by a superscripted letter differ significantly from controls $(\mathrm{P}<0.05)$ based on Dunnett's or Dunn's test.

Statistical analysis of variance for examination of interaction between species and freezing on stem electrolyte leakage, chlorophyll fluorescence, and RGP

Variate: Stem electrolyte leakage

Source of variation

Species

Freezing

Species $\times$ freezing

Residual

Total d.f.

6

12

189

209
S.S.

\section{7}

34047

7447

1669

45890
Variate: Chlorophyll fluorescence
Source of variation

Species

Freezing

Species $\times$ freezing

Residual

Total

Variate: RPG

Source of variation

Species

Freezing

Species $\times$ freezing

Residual

Total d.f.

$2 \quad 0.058$

$6 \quad 42.63$

$12 \quad 5.01$

819

839

d.f. S.S.

$2 \quad 1237$

$6 \quad 1217$

$12 \quad 145$

294

314

3410 m.s.

1363

5674

620

8.83

0.96

46.75

m.s

7.10

0.41

0.00 v.r.

154

642

70

v.r.

24.9

6052

355
F. pr

$<0.001$

$<0.001$

$<0.001$

m.s.

618

203

12.15

2.75 v.r.

225

73

4.41
F. pr

$<0.001$

$<0.001$

$<0.001$

$808 \quad 2.75$


Table 3. Average for three species (birch, holly, and evergreen oak) of correlation analysis $\mathbf{r}^{2}$ values obtained by comparing the results of three physiological tests to those from a field performance trial.

\begin{tabular}{llll}
\hline Growth attribute & $\begin{array}{l}\text { Stem } \\
\text { electrolyte leakage }\end{array}$ & $\begin{array}{l}\text { Chlorophyll } \\
\text { fluorescence (Fv/Fm) }\end{array}$ & $\begin{array}{l}\text { RGP (number of } \\
\text { roots } \geq 1 \mathrm{~cm})\end{array}$ \\
\hline Survival & $0.93(5.68)$ & $0.94(0.08)$ & $0.69(2.22)$ \\
Foliar damage & $0.96(4.29)$ & $0.95(0.07)$ & $0.70(2.19)$ \\
Height increment & $0.63(11.87)$ & $0.50(0.20)$ & $0.85(1.60)$ \\
\hline
\end{tabular}

Values in parentheses are standard errors of $\mathrm{r}^{2}$.

\section{Birch}
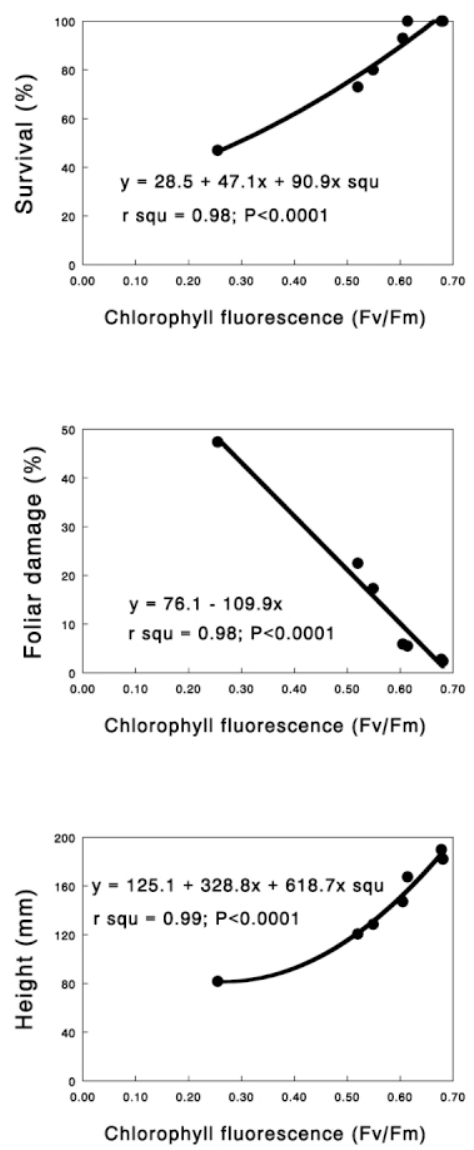

Holly
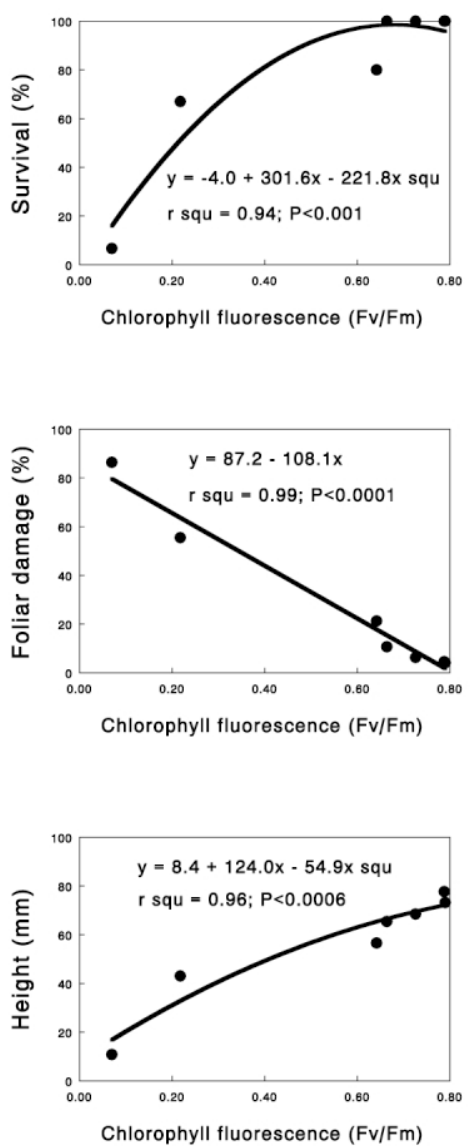

Evergreen oak
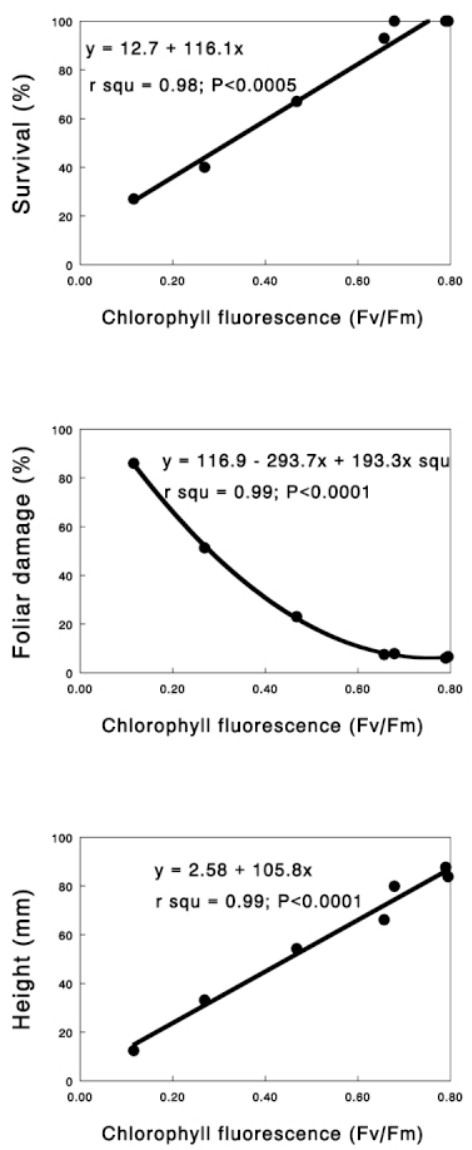

Figure 1. Relationship of chlorophyll fluorescence (Fv/Fm) with survival, foliar damage, and height increment of birch (Betula pendula), holly (Ilex aquifolium), and evergreen oak (Quercus ilex) trees at week 17 post-freezing under field conditions. 
Birch
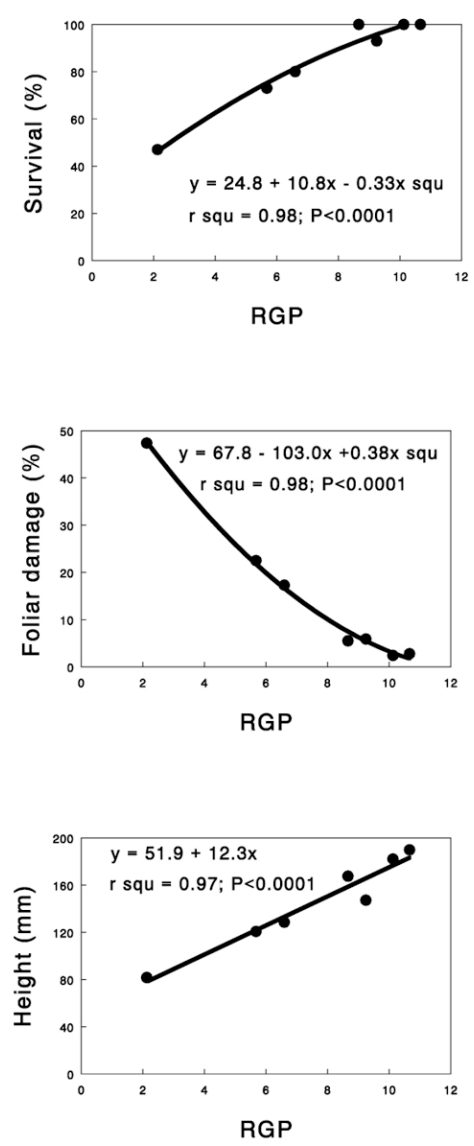

Holly
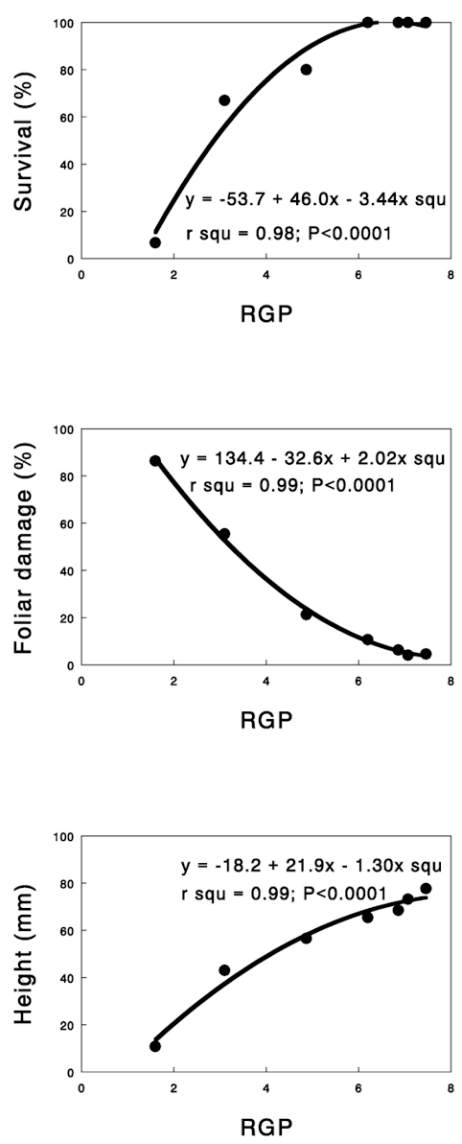

Evergreen oak
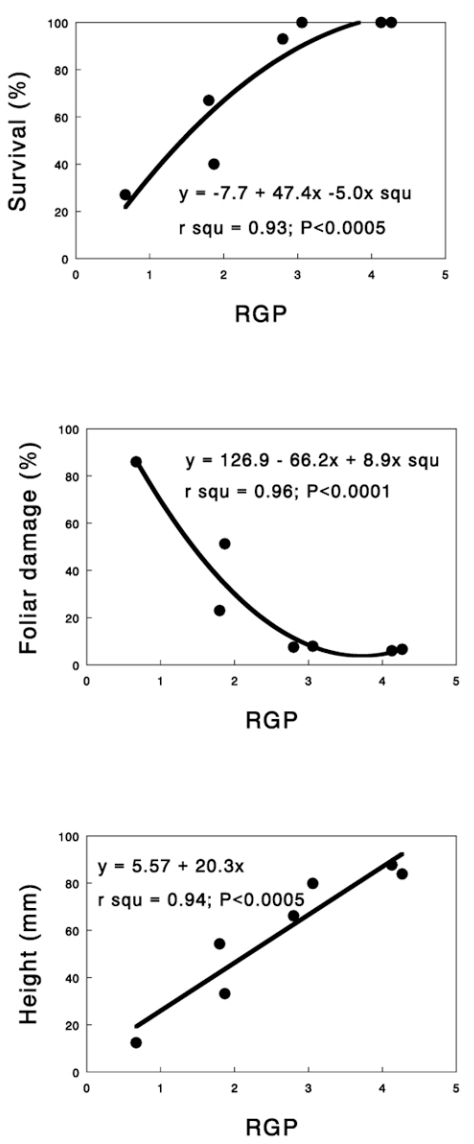

Figure 2. Relationship of root growth potential (RGP) with survival, foliar damage, and height increment of birch (Betula pendula), holly (Ilex aquifolium), and evergreen oak (Quercus ilex) trees at week 17 post-freezing under field conditions. 


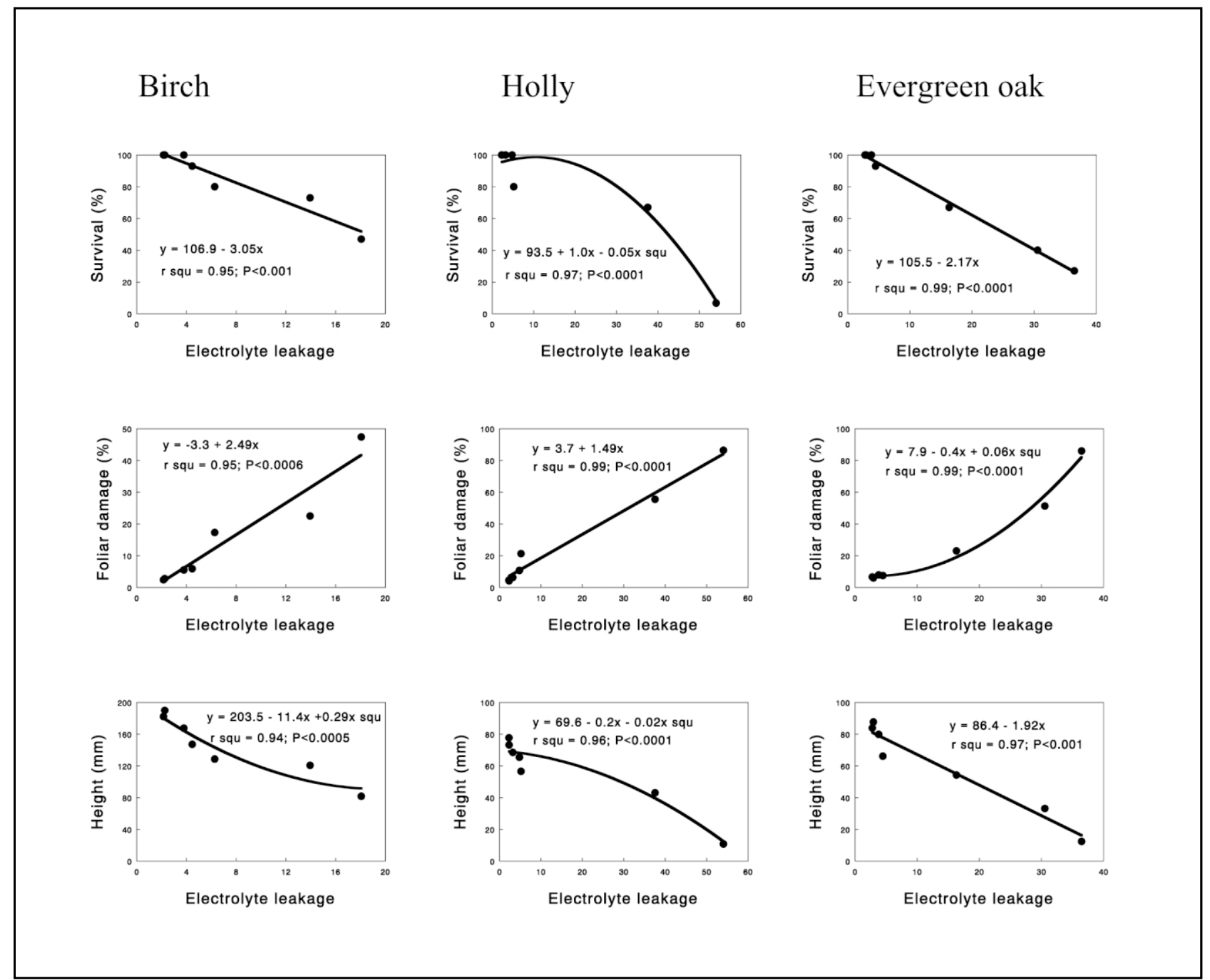

Figure 3. Relationship of stem electrolyte leakage with survival, foliar damage, and height increment of birch (Betula pendula), holly (Ilex aquifolium), and evergreen oak (Quercus ilex) trees at week 17 post-freezing under field conditions. 
Résumé. Des taux élevés de mortalité de stocks à racines nues peuvent parfois se produire après la plantation, et ce en raison d'une faible vitalité chez la plante au moment de la plantation. Des tests physiologiques de la vitalité de la plante, tels que la perte en électrolyte de la tige, le potentiel de croissance racinaire et la fluorescence de la chlorophylle, sont utiles en raison de leur capacité à identifier les plantes peu vigoureuses ou endommagées qui vont mal performer lors de leur plantation sur le site. Les taux de survie, de croissance et de dommages foliaires de trois espèces d'arbres communément employées en aménagement ont été prédits avec précision par les tests de perte en électrolyte de la tige, de potentiel de croissance racinaire et de fluorescence de la chlorophylle, et ce 17 semaines après la plantation suite à des dommages par le gel. Des trois tests physiologiques, les corrélations entre les valeurs moyennes de $\mathrm{r}^{2}$ de performance réelle sur le terrain et celles à partir du test de perte en électrolyte de la tige étaient les plus élevées; donc, en se basant sur ces résultats, ce test était marginalement meilleur comme « évaluateur » de la performance future des plantes que les deux autres tests. Les mesures de fluorescence de la chlorophylle prises à partir des tissus ligneux du bouleau, une espèce décidue, étaient hautement fiables pour déterminer le taux de survie subséquent, les dommages foliaires et l'augmentation en hauteur 17 semaines après la plantation; ceci indique donc que la fluorescence de la chlorophylle peut avoir des applications comme « évaluateur» de la vitalité d'une plante et de sa croissance future chez les espèces feuillues. Les avantages pratiques et les désavantages offerts par chacun de ces tests, et ce pour les professionnels impliqués dans la gestion des arbres en milieu urbain, sont discutés.

Zusammenfassung. Hohe Sterblichkeitsraten bei Wurzelware können gelegentlich nach dem Pflanzen auftreten, wenn die Vitalität vor dem Pflanzvorgangs gering war. Infolgedessen sind physiologische Prüfungen der Pflanzenenergie, wie das Auslaufen von Stammelektrolyten, Wurzelwuchspotential und Chlorophyllfluoreszenz wegen ihrer Fähigkeit, niedrige Vitalität von Pflanzmaterial zu identifizieren, bevor es ausgepflanzt wird. Das Überleben, der Wuchs und die Blattschäden von drei Baumarten, die im Allgemeinen in der Landschaft gepflanzt werden, wurden 17 Wochen nach dem Pflanzen genau durch o. g. Parameter unter Feldbedingungen und vorangegangenem
Frostschaden vorherbestimmt. Von den drei physiologischen Tests hatten die Korrelationen zwischen dem Elektrolytaustritt und Entwicklung im Feldversuch die höchsten mittleren $\mathrm{r}^{2}$-Werte und basierten daher auf Ergebnissen dieser Untersuchung im Randbereich besser als ein Vorhersagemittel für zukünftige Pflanzenentwicklung im Vergleich zu Wurzelwuchspotential und Chlorophyllfluoreszenz. Die von Birkengewebe genommenen Chlorophyllfluoreszenzmesswerte waren 17 Wochen nach der Pflanzung sehr aussagekräftig für nachfolgendes Überleben, Blattschäden und Höhenwachstum und zeigten, dass Chlorophyllfluoreszenz möglicherweise als Kriterium um Pflanzenvitalität und zukünftiges Wachstum bei Laubgehölzen zu bestimmen, eingesetzt werden kann. Die praktischen Vorteile und Nachteile durch jeden Vitalitätstest, wie sie sich den Praktikern aus den urbanen Landschaftsbau präsentieren, werden hier besprochen.

Resumen. Altas tasas de mortalidad de plantas a raíz desnuda pueden ocurrir ocasionalmente post plantación debido a su pobre vitalidad al momento de la plantación. Consecuentemente, pruebas fisiológicas de vitalidad de las plantas tales como electrólisis del tallo, potencial de crecimiento de la raíz (PCR) y fluorescencia de clorofila, son valiosas debido a su capacidad para identificar el bajo vigor o daño de las plantas que hacen que éstas tengan un pobre desempeño cuando se planten. La supervivencia, daño foliar y crecimiento de tres especies de árboles comúnmente usado en plantaciones fueron evaluados con pruebas de electrolitos, PCR y fluorescencia, 17 semanas post plantación bajo condiciones de campo. De las tres pruebas fisiológicas, las correlaciones $\left(\mathrm{r}^{2}\right)$ de las pruebas con electrolitos tuvieron el más alto valor medio y como resultado de esta investigación, son un indicador del futuro de una planta en comparación con las otras dos pruebas. Las mediciones de fluorescencia de clorofila tomadas del tejido maderable de abedul, una especie decidua, fueron altamente predictivas de la supervivencia subsiguiente, daño foliar e incremento en altura, 17 semanas post plantación, indicando que este puede ser un indicador de la vitalidad y futuro crecimiento en árboles ornamentales deciduos. Se discuten las ventajas prácticas y las desventajas ofrecidas para cada prueba, para los profesionales en el manejo de áreas verdes urbanas. 